Litteratur

1. Sjaastad O, Hesselberg JP. Ensidig om nakkesleng fra Høyesterett. Tidsskr Nor Legeforen 2014: 134: 721-4.

2. Schrader $\mathrm{H}$, Obelieniene $\mathrm{D}$, Bovim $\mathrm{G}$ et al. Natural evolution of late whiplash syndrome outside the medicolegal context. Lancet 1996; 347: 1207-11.

3. Obelieniene D, Schrader H, Bovim G et al. Pain after whiplash: a prospective controlled inception cohort study. J Neurol Neurosurg Psychiatry 1999: 66: 279-83.

\section{Re: Ensidig om nakkesleng fra Høyesterett}

Stovner har med sine kommentarer brakt oss i forskjellige retninger, og det kan være på sin plass å summere litt.

For det første, Stovner har i sitt siste innlegg ikke nevnt noe mer om den betydelige mannsovervekten i Litauen-materialet. Dette innebærer kanskje at han innser at han må leve med denne skavanken ved materialet.

For det andre, vi skrev opprinnelig at tidsintervallet fra nakkeslengskade til studiestart var gjennomsnittlig 21.7 måneder, og dette viser klart tilbake på Schrader og medarbeideres første artikkel i Litauen-undersøkelsene (1). Stovner repliserer: «For det første er dette feil». Feil? Dette er det riktige tallet. Stovners opplysninger er tatt fra en helt annen undersøkelse i Litauen-serien, som ikke er omtalt av oss.

For det tredje, den manglende muligheten for økonomisk kompensasjon ved nakkeslengskade i Litauen er et hovedtrekk, som vi har kjent til lenge. I artikkelen vår skrev vi: «Noen karakteristika var meget gunstige - for eksempel at det ikke var noen økonomisk kompensasjon å få for de skadelidte». Og i vårt første svar: «- nakkesleng $\mathrm{i}$ et land uten noen form for økonomisk kompensasjon, noe vi mente var en god idé». Besynderlig nok tar Stovner dette opp igjen i sitt siste innlegg. Denne del av disputten bør opphøre.

I hans siste innlegg er vi også blitt tillagt så vidt bisarre meninger at våre tanker sviver i retning av et av Piet Heins berømte «Gruk»: «- at dytte en annen en mening på, hvis vanvidd alle kan forstå» (fritt sitert). Stovner skriver at vi «synes å mene» at man i nakkeslengstudier kan «velge ut de som etter en slik hendelse enten selv har definert seg som pasient, eller av lege har blitt definert som pasient».

Vi har ikke sagt, skrevet eller ment noe som er i nærheten av det som her blir hevdet. Det er generelt en klar forutsetning for nakkeslengstudier at der er utført en «terskel-test», en prøve, på hvor store plagene er (se vår opprinnelige artikkel for nærmere detaljer (2)). Mange påkjørsler bakfra er ikke sterke nok til å skape et nakkeslengsyndrom. Hvor mange det vil være i denne kategorien og hvor mange det vil være av pasienter med sterkere plager i Litauenstudien, er det ingen gitt å vite. Siden en slik vurdering/test ikke lot seg inkorporere i Litauen-materialet, så blir Litauen-undersøkelsen en umulighet. Men dette er noe helt annet enn det vi, ifølge Stovner, "synes å mene».

Dette er veldig synd. Den tilgrunnliggende idéen - teorien - var veldig god, men den lot seg dessverre ikke gjennomføre i praksis.

Stovner skriver at han er glad for vår erkjennelse av sammenhengen mellom kroniske plager og psyke. Da har han vært glad lenge, for han har kjent oss i 30 år.

\section{Ottar Sjaastad}

ellhed@online.no

Johan Petter Hesselberg

Ottar Sjaastad (f. 1928) er dr.med., spesialist i nevrologi, pensjonert overlege og professor.

Ingen oppgitte interessekonflikter.

Johan Petter Hesselberg (f. 1932) er spesialist i nevrologi og pensjonert overlege.

Ingen oppgitte interessekonflikter.

\section{Litteratur}

1. Schrader H, Obelieniene D, Bovim G et al. Natural evolution of late whiplash syndrome outside the medicolegal context. Lancet 1996; 347: 1207-11.

2. Sjaastad O, Hesselberg JP. Ensidig om nakkesleng fra Høyesterett. Tidsskr Nor Legeforen 2014; 134: $721-4$

\section{Re: Nye retningslinjer for antitrombotisk behandling og tromboseprofylakse}

Tidsskriftet nummer 9/2014 er breddfull av ny kunnskap innen mitt hovedområde da jeg var på Institutt for tromboseforskning i siste halvdel av forrige århundre. Nå er kunnskapen blitt så komplisert at jeg ville vært sjanseløs om det var slik den gang. Så god hjerne har jeg ikke. Jeg ventet at nye resultater skulle gjøre det enklere både for pasienten og oss selv. Men det omvendte har skjedd. Med så mange alternativer som foreligger må de som doserer nå til dags være $\mathrm{i}$ en pinefull situasjon overfor hver eneste dosering. Hvor ofte vil de våkne og klø seg i hodet - skulle jeg heller gitt tablett a eller b, og ga jeg i meste eller minste laget?

For oss gamle som ikke hadde tilgang til så mye kunnskap, kan det lett hende at vi ulovlig har hjulpet mange ut av livet. Da er man henfallen til straff, og det er tungt å tenke på.

Men, kanskje vi som bot tok i bruk et enkelt inngrep som muliggjør at vi allikevel har gjort noe bra: heve fotenden av sengen 5-7 centimeter for alle voksne. Da vil også mange ektefeller bli unødig med, men de har ikke vondt av det.

Dette er noe jeg har observert, og det er riktignok ikke klart bevist. Men sjansen for at jeg tar feil er liten (det gjelder bare her). Og skulle så skje har ikke pasienten lidd overlast - hevingen er ikke smertefull. Jeg har erfaring.

De fleste har sikkert fått dette med seg, men blir det fulgt opp? Hvis ikke: sett i gang en studie!

\section{Helge Stormorken}

hestormo@frisurf.no

Helge Stormorken (f. 1922) er pensjonert lege og tidligere professor i medisin ved Universitetet i Oslo. Han var bestyrer for Rikshospitalets Institutt for tromboseforskning 1963-80.

Ingen oppgitte interessekonflikter.

Litteratur

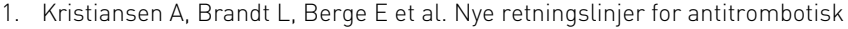
behandling og tromboseprofylakse. Tidsskr Nor Legeforen 2014: 134: 921 -2.

\section{Re: Når kreftene renner vekk}

Mange kommuner har kreftkoordinatorer. Å informere om fatigue, som denne artikkelen handler om (1), er en viktig del av kreftkoordinatorers jobb. Vi kan komme på hjemmebesøk eller ha samtaler med pasient og pårørende på kontoret, på sykehuset eller over telefon. Jeg oppfordrer alle som arbeider med kreftpasienter og deres pårørende til å ta kontakt med kreftkoordinator i kommunen. Kreftkoordinator er et viktig bindeledd mellom spesialisthelsetjeneste og kommune.

\section{Anne-Gun Agledal \\ anne.gun.agledal@drmk.no}

Anne-Gun Agledal (f. 1961) er kreftkoordinator i Drammen kommune. Oppgitte interessekonflikter: Jobber selv som kreftkoordinator.

Litteratur

1. Brekke TK. Når kreftene renner vekk. Tidsskr Nor Legeforen 2014; 134: 950.

\section{T. Kind Brekke svarer:}

Jeg setter pris på Anne-Gun Agledals oppfordring om at alle som arbeider med kreftpasienter og deres pårørende bør ta kontakt med kreftkoordinatoren i kommunen. Det er ikke så lett for en ny kreftpasient å vite om muligheten og å ta kontakt selv. Det betyr mye og kan være til stor hjelp å kunne få samtale i fred og ro med en fagperson. Det er fint og viktig at kreftkoordinatoren kan informere om fatigue.

Jeg håper artikkelen kan være et godt arbeidsverktøy i kreftkoordinatorenes informasjonsarbeid. Jeg fikk tilbakemeldinger på artikkelen 